\title{
PENALARAN MORAL ANAK DALAM CERITA ANAK PADA MAJALAH BOBO DAN HARIAN KOMPAS
}

\author{
Heru Kurniawan ${ }^{1}$, Herman J. Waluyo ${ }^{2}$, Sarwiji Suwandi ${ }^{3}$, Budhi Setiawan ${ }^{4}$ \\ Universitas Sebelas Maret Surakarta (UNS) \\ heru_1982@yahoo.com, herman.jwaluyo@yahoo.co.id, \\ sarwijiswan@yahoo.com, buset.74@gmail.com.
}

\begin{abstract}
Abastrak
Cerita-cerita anak pada Majalah Bobo dan Harian Kompas merepresentasikandua tingkatan penalaran moral prakonvensional dan konvensional. Dari dua tingkatan penalaran moral itu, terdapat tiga tahapan penalaran moral anak, yaitu penalaran moral kepatuhan hukuman,penalaran moral relativis-instrumen, dan penelaran moral aku anak baik. Dari ketiga penalaran moral ini, penalaran moral anak yang dominan adalah relativis-instrumen dan orientasi anak baik, sedangkan penalaran kepatuhan tidak mendominasi. Hal ini menunjukkan bahwa kesadaran moral bersama atas anak-anak bersifat transaksional dan eksistensial, yaitu anak-anak dikondisikan berbuat baik karena ingin mendapatkan hadiah, dan kesadaran keinginannya untuk menjadi anak baik. Dengan kenyataan cerita anak yang demikian, maka anak-anak kita yang membaca cerita anak pun terbangun kesadaran bahwa saya berbuat baik karena adanya hadiah dan kesadaran untuk menjadi anak baik.
\end{abstract}

Kata Kunci: penalaran moral; cerita anak; kepatuhan hukuman; relativis instrument; aku anak baik.

\begin{abstract}
Children's stories in Bobo Magazine and Kompas Daily represent both levels of praconventional and conventional moral reasoning. From these two levels of moral reasoning, there are three stages of a child's moral reasoning, namely moral reasoning for obedience of punishment, relativist-instrument moral reasoning, and moral reasoning of a good child. Of these three moral reasoning, the dominant moral reasoning of children is the relativist-instrument and the orientation of a good child, while obedience reasoning does not dominate. This shows that mutual moral awareness of children is transactional and existential, namely children are conditioned to do good because they want to get a prize, and awareness of their desire to be good children. With the reality of such children's stories, our children who read children's stories wake up to the realization that I am doing good because of the gifts and awareness to be a good child.
\end{abstract}

Keywords: moral reasoning; children's stories; obedience of punishment; instrument relativism; I'm a good child.

\section{Pendahuluan}

Salah satu aspek penting cerita anak adalah adanya unsur hiburan dan pemahaman (moral) (Lukens, 2003: 4), yang sering disebut dengan sweet and usefull atau nikmat dan bermanfaat (Nurgiyantoro, 2010: 31). Hiburan dan pemahaman ini mensyaratkan bahwa cerita anak yang baik harus mengandung kepaduan unsur nilai hiburan dan nilai moral yang baik dan kompleks. Arlene M. Pilla (1979: 148) dalam penelitiannya terhadap aspek moral cerita anak menyebutkan bahwa persoalan moral dalam cerita anak merupakan 
hal yang harus selalu ada. Melalui persolan moral yang disajikan dalam alur cerita yang menarik itulah yang membuat cerita anak menjadi kompleks dan kaya sehingga akan disukai pembaca anak-anak.

Akan tetapi, kenyataan yang terdapat di cerita anak di Indonesia, terutama cerita anak yang dipublikasikan pada majalahmajalah anak, menunjukkan aspek hiburan dan moral dalam bacaan anak itu tidak bersinergi dengan baik. Banyak cerita anak yang hanya monoton dari aspek moralnya saja dan mengabaikan aspek hiburannya, sehingga cerita anak seperti bahan untuk menasihati anak. Sebaliknya, banyak cerita anak yang hanya menonjolkan aspek hiburan, tetapi tidak ada (minim) nilai moralnya, sehingga cerita anak seperti bahan hiburan saja. Untuk itulah, dari kenyataan ini yang menjadikan salah satu faktor perkembangan sastra anak-anak di Indonesia tertinggal (Purbani, 2003: 1 - 5; Sugihastuti, 2000: 39) dibanding dengan sastra anak di negara lain. Hal ini tampak bahwa anak-anak lebih sering membaca cerita anak terjemahan dari negara lain daripada cerita anak negeri sendiri (Purbani, 2003: 2) karena aspek hiburan dan pemahamannya proporsional dan kompleks.

Kenyataan di atas menunjukkan bahwa cerita anak substansinya terbangun oleh kepaduan unsur-unsur cerita yang menarik dalam menyampaikan nilai moral yang memberikan pemahaman pada anak. Aspek kemenarikan unsur-unsur cerita berkaitan dengan penyajian unsur-unsur pembangun cerita, seperti tokoh, latar, tema, dan alur yang unik dan menghibur. Sedangkan, pada aspek moral, cerita anak harus menyuguhkan nilai dan moral secara implisit yang sesuai dengan perkembangan penalaran moral (moral reasoning) anak.
Hal ini didasarkan kenyataan teoretis bahwa nilai moral selalu memiliki penalaran (Kohlberg, 1995: 23; Duska \& Mariellen Whelan, 1982: 5) karena moral tidak hanya mengenai baik dan buruk saja, tetapi juga menyangkut bagaimana struktur nilai baik dan buruk itu dibangun, yang dalam istilahnya Kohlberg (1995: 25) disebut penalaran moral (moral reasoning). Penstrukturasian nilai moral inilah yang kemudian melahirkan penalaran, yaitu mengenai cara pikir dan rasionalisasi lahirnya sebuah nilai moral, terutama nilai moral yang disampaikan dalam sebuah cerita anak, baik yang bersifat tersirat maupun tersurat dalam setiap peristiwa dan struktur cerita yang dibangun.

Berdasarkan penjelasan di atas, maka persoalan yang muncul adalah bagaimana dengan penalaran moral cerita anak di Indonesia? Di sini Harian Kompas danmajalah anak Bobo dijadikan sebagai fokus penelitian karena alasan:keduanya merupakan media massa dan majalah anak yang usianya paling tua di Indonesia, mampu bertahan lebih beberapa dekade dengan tetap konsisten ada rubrik cerita anak dari awal sampai sekarang; keduanya memuat rubrik favorit anak-anak yang dalam satu kali terbitnya setiap minggu memuat banyak cerita anak; cerita anak dalam harian Kompas dan majalah anak Bobo banyak dijadikan sumber bacaan cerita anak untuk buku-buku di sekolah; dan cerita anak dalam harian Kompas dan majalah Bobo isinya selalu menampilkan realitas kehidupan anak-anak saat ini.

\section{Penalaran Moral Anak}

Kohlberg (1981: 15) dalam hal ini menjelaskan pengertian moral menggunakan istilah seperti moral-reasoning, moral-thinking, dan moral -judgement (dan istilah yang popular kemudian adalah moral-reasoning) sebagai istilah yang 
dapat dibahasakan menjadi "penalaran moral". Hal ini menunjukkan bahwa moral selalu berakar pada prinsip-prinsip rasionalitas (Dua, 2011: 14). Penalaran moral ini menekankan pada alasan mengapa suatu tindakan dilakukan, daripada sekadar arti suatu tindakan, sehingga dapat dinilai apakah tindakan tersebut baik atau buruk. Kohlberg (1981: 24) juga tidak memusatkan pada pernyataan (statement) orang tentang apakah tindakan orang itu benar atau salah, tetapi kepada penalaran terhadap tindakan yang dilakukan oleh individu.

Serangkaian penelitian yang dikembangkan Kohlberg dalam perkembangan penalaran moral manusia menunjukkan bahwa penalaran-penalaran yang diajukan seseorang selalu didasarkan pada pertimbangan moral tertentu, misalnya, seseorang menunjukkan bahwa berbuat curang itu salah karena dapat ditangkap, sedangkan orang lain menunjukkan bahwa berbuat curang itu salah karena merongrong kepercayaan umum yang dibutuhkan untuk berlangsungnya masyarakat. Hal ini menunjukkan adanya perbedaan-perbedaan yang berarti dalam pandangan moral seseorang (Duska \& Whelan, 1982: 57). Akan tetapi, keberbedaan alasan yang dikemukakan setiap orang dalam merasionalisasi tindakannya memiliki adanya struktur (Magnis-Suseno, 2000: 156). Struktur inilah yang kemudian dikembangkan oleh Kohlberg (1980: 29 - 37) menjadi teori perkembangan penalaran moral manusia yang meliputi tiga tahap perkembangan sebagai berikut.

Tingkatan Pra-konvensional, tahap pra -konvensional merupakan tingkat penalaran terendah manusia, yang penilaian baik dan buruk diinterpretasikan melalui reward (imbalan) dan punishment (hukuman) ek- sternal (Santrock, 2012: 119). Dalam penalaran ini terdapat dua tahap: Tahap 1, Orientasi Hukuman dan Kepatuhan, merupakan tahap moralitas heterogen, yaitu tahap pertama pada tingkat penalaran prakonvensional yang menunjukkan penalaran moral terkait dengan punishment karena anak berpikir bahwa kepatuhan terjadi karena takut pada hukuman (Santrock, 2007: 119); dan Tahap 2, Orientasi relativis instrumen, yaitu tahap anak memikirkan kepentingan sendiri mengenai hal yang benar, yang juga akan berlaku untuk orang lain. Anak mulai menalar tentang pertukaran setara, jika berbuat baik pada orang lain, maka orang lain akan berbuat baik juga pada dirinya (Santrock, 2011: 119).

Tingkatan Penalaran Konvensional, penalaran konvensional merupakan penalaran kedua atau menengah, yaitu penalaran individu yang mulai memberlakukan standar tertentu, tetapi standar itu ditetapkan oleh orang lain (Santrock, 2007: 119). Dalam penalaran ini terdapat dua tahap:Tahap 3: orientasi masuk ke kelompok "anak baik" dan "anak manis",yang sering disebut juga tahap ekspektasi interpersonal mutual, hubungan dengan orang lain, dan konformitas interpersonal, yaitu individu sudah menghargai kepercayaan, perhatian, dan kesetiaan terhadap orang lain sebagai dasar penalaran moralnya. Tahap ini menunjukkan peralihan anak ke remaja yang sering kali mengadopsi standar moral orang tua agar dianggap orang tua sebagai anak yang baik (Santrock, 2007: 119 \& Crain, 2007: 233); dan Tahap 4: orientasi Hukum dan Ketertiban, yaitu tahap penalaran moral yang didasari oleh pemahaman tentang keteraturan di masyarakat, hukum, keadilan, dan kewajiban (Santrock, 2007: 119). Dalam tahap ini individu menyadari adanya orientasi pada otoritas, peraturan-peraturan yang pasti, dan usaha memelihara ketertiban sosial. 
Tingkah laku yang benar berupa melakukan kewajiban, menunjukkan rasa hormat kepada otoritas, dan memelihara ketertiban sosial yang sudah ada demi ketertiban itu sendiri (Kohlberg, 1980: 92; Duska \& Whelan, 1982: 60 - 61; K. Bertens, 2002: 83; dan Mathias, 1987: 17).

\section{Tingkatan Pasca-konvensional, Otonom} atau Berprinsip, pada tingkatan ini ada usaha yang jelas untuk mengartikan nilainilai moral dan prinsip-prinsip kebenaran serta dapat dilaksanakan, terlepas dari otoritas kelompok atau orang yang memegang prinsip-prinsip tersebut, dan terlepas dari apakah individu bersangkutan termasuk kelompok-kelompok itu atau tidak (Duska \& Whelan, 1982: 61): Tahap 5: Orientasi Kontrak Sosial-Legalitas, individu bertindak benar dengan kecenderungan bisa dimengerti dari segi hak-hak individualnya yang umum dan dari segi ukuran-ukuran yang sudah dikaji dengan kritis dan disetujui oleh anggota masyarakat. Ada kesadaran yang jelas bahwa nilai-nilai dan opini pribadi itu relatif dan oleh karenanya perlu adanya peraturan prosedural untuk mencapai konsensus (Duska \& Whelan, 1982: 61), dan Tahap 6: Orientasi Azas Etika Universal, yaitu tahap individu dapat mengembangkan standar moral berdasarkan hak manusia universal, individu dapat mengatasi pertentangan antara hukum dan hati nurani, individu menalar bahwa yang diikuti adalah hati nurani, meskipun keputusannya dapat memberikan resiko (Santrock, 2002: 120).

\section{Sastra Anak}

Sastra anak merupakan dunia yang distrukturasi oleh unit-unit pembangun sastra, Lukens (2003: 10) mendefinisikan salah satu aspek pembangun sastra anak adalah kese- nangan dan pemahaman. Sastra anak hadir kepada pembaca anak-anak adalah untuk memberikan hiburan yang menyenangkan karena menampilkan cerita yang menarik, mengajak pembaca untuk memanjakan fantasi, membawa pembaca ke suatu alur kehidupan yang penuh dengan daya suspense, daya yang menarik hati pembaca untuk ingin tahu dan terikat karenanya, dan kesemuanya dikemas dengan menarik sehingga pembaca mendapatkan kesenangan dan hiburan. Di sisi lain, karena sastra selalu membahas tentang kehidupan, maka sastra anak juga memberikan pemahaman yang lebih baik pada pembaca tentang kehidupan. Pemahaman itu datang dari eksplorasi terhadap berbagai bentuk kehidupan, rahasia kehidupan, penemuan dan pengungkapan berbagai karakter manusia, danlain-lain. Informasi inilah yang kemudian memperkaya pengetahuan dan pemahaman pembaca (anak-anak).

Saxby (1991: 4) menjelaskan bahwa sastra nak hakikatnya adalah citra dan gambaran kehidupan. Citra kehidupan (image of life) dapat dipahami sebagai penggambaran secara konkret tentang model-model kehidupan sebagaimana dijumpai dalam kehidupan faktual sehingga mudah diimajinasikan sewaktu dibaca. Berdasarkan pengertian ini, sastra anak adalah sastra yang citraan dan metafora yang dikisahkan itu berada dalam jangkauan anak, baik yang melibatkan aspek emosi, perasaan, pikiran, saraf sensori, maupun pengalaman moral, dan diekspresikan dalam bentuk kebahasaan yang juga dapat dijangkau dan dipahami oleh anak-anak. Hal ini menunjukkan bahwa sastra anak adalah sastra yang menempatkan sudut pandang anak sebagai pusat penceritaan (Norton, 1987: 6).

Sastra anak adalah dunia yang kompleks, yang pengertiannya tidak bisa disederhanakan dengan satu tujuan tertentu. Hunt (1995: 43 - 
44) menjelaskan bahwa tidak ada definisi tunggal dalam sastra anak karena sastra anak dapat dilihat konsepsinya melalui berbagai persepsi, misalnya, dari aspek pendidikan, bahasa, sosial, hiburan, dan budaya. Namun demikian, dari kompleksitas persepsi untuk mendefinisikan sastra anak, Hunt (1995: 51) mengkategorikan definisi sastra anak dapat dilihat dari tiga aspek, yaitu definisi berdasarkan pada karakteristiknya, definisi berdasarkan norma-norma budaya, dan definisi berdasarkan pemanfaatan karya sastra anak oleh pembaca.

Pertama, pengertian sastra anak dari aspek karakteristiknya dapat dilihat pada ciri utama sastra adalah karya imajinatif yang bermediakan bahasa dan mempunyai nilai estetika dominan (Wellek \& Warren, 1995: 15). Sastra anak sebagai hasil imajinatif mencirikannya pada aspek bahasa sebagai media dan estetika yang merupakan konsep dasar seni yang bersifat personal yang perwujudannya direpresentasikan melalui strukturnya. Karakteristik ini menegaskan sastra anak adalah hasil imajinasi manusia yang ditinjau dari aspek estetika (isi), struktur, dan bahasa sesuai yang khas (Hunt, 1995: 51), yaitu sesuai dengan tingkat perkembangan dan kemampuan anak.

Kedua, ditinjau dari norma-norma budaya, sastra anak merepresentasikan kehidupan sosial dan budaya anak. Sastra anak adalah sastra yang sesuai dengan budaya anak, sehingga dalam memahaminya, anak tidak mendapatkan problem budaya, sebaliknya sastra anak berfungsi untuk memperluas pengalaman anak (Hunt, 1995: 53) dalam memahami nilai-nilai yang menjadi sistem budaya. Nilai atau makna dalam sastra hakikatnya adalah substansi yang dikemas dalam peristiwa-peristiwa yang digambarkan kehidupan pada sastra anak, dan nilai-nilai ini haruslah sesuai dengan konteks budaya anak. Oleh karena itu, dengan batasan nilai dan norma budaya, khayalan dalam sastra anak, bukanlah khayalan yang "bohong" karena khayalan dalam sastra anak berangkat dari realitas dan budaya yang melatarinya.

Ketiga, sastra anak batasannya didasarkan pada pemanfaatannya untuk pembaca anakanak, yaitu sastra anak harus bermanfaat bagi anak dan isinya sesuai dengan perkembangan anak. Huck (1987: 5) mendefinisikan sastra anak adalah sastra yang sesuai dengan pengalaman dan pemahaman anak, yaitu sesuai dengan perkembangan emosional dan psikologis anak. Kesesuaian sastra anak dengan perkembangan anak menegaskan sastra anak memiliki fungsifungsi khusus, Pantaleo (2002: 21) menjelaskan bahwa sastra anak keberadaannya bagi anak harus bisa mengembangkan pengalaman estetis yang menyenangkan, menghibur, meningkatkan imajinasi, meningkatkan rasa kasih sayang dan pengetahuan, serta menanamkan nilai-nilai. Tentu saja, fungsi ini bisa tercapai jika sastra anak diciptakan sesuai dengan perkembangan anak.

Ketiga definisi di atas menegaskan bahwa sastra anak dapat ditinjau pengertiannya dari sudut karakteristik, baik logika maupun bahasa; budaya; dan implikasi (Hunt, 1995: 53). Oleh karena itu, sastra anak adalah karya sastra yang struktur, logika, bahasa mudah dipahami oleh anak-anak, menyampaikan nilai-nilai dalam konteks budaya anak, dan ditujukan untuk anak dalam rangka untuk mengembangkan potensi anak. Sastra anak adalah sastra dengan ciri khasnya pada kesesuaian dengan perkembangan imajinasi, intelektual, sosial, dan moral anak-anak.

Penelitian ini adalah deskriptif yang diorientasikan untuk mengeksplorasi dan klarifi- 
kasi mengenai suatu fenomena atau kenyataan sosial dengan jalan mendeskripsikan sejumlah variabel yang berkenaan dengan masalah atau unit yang diteliti (Faisal, 2010: 20). Penelitian deskriptif ini akan mengeksplorasi dan mengklarifikasi fenomena "penalaran moral anak" sebagai objek formal yang terdapat dalam unit (material) teks sastra, yaitu cerita anak yang terdapat di majalah bacaan anak Bobo dan Kompas. Model penelitian deskriptif-teks ini menurut Ratna (2011: 197) bahwa sebuah karya sastra dapat dianalisis dan diteliti secara langsung dan objektif mengenai fenomena-fenomena yang terdapat di dalamnya. Dalam hal ini, jenis penelitian deskriptif-tekstual ini dilakukan dengan penelitian analisis isi (contentanalysis), yaitu teknik penelitian yang bertujuan untuk membuat inferensi-inferensi yang dapat ditiru (replicable) dengan memperhatikan konteksnya (Bungin, 2009: 156). Dalam deskriptif ini, analisis isi ini ditekankan pada pemaknaan isi, membaca simbol-simbol, dan struktur-struktur yang terdapat dalam karya sastra sebagai teks untuk memahami fenomena penalaran moral.

Analisis data dalam penelitian kualitatif berkaitan dengan proses mencari dan menyusun secara sistematis data-data penelitian dengan cara mengorganisasikan data ke dalam kategori, menjabarkan ke dalam unitunit, melakukan sintesa, menyusun ke dalam pola, dan membuat simpulan sehingga mudah dipahami oleh pembaca (Bogdan \& Biklen, 2006: 198; Sugiyono, 2010: 335). Analisis datanya fokusnya pada deskripsi, penjernihan, dan penempatan data pada konteksnya yang dideskripsikan dengan kata-kata (Faisal, 2010: 256) dengan tujuan untuk menghasilkan dan mengungkapkan maknamakna dan teori baru (Ratna, 2011: 303). Da- lam konteks ini, teknik analisis data yang digunakan dalam penelitian ini menggunakan model analisis menurut Miles \& Huberman (2009: 15 - 20), yang meliputi pengumpulan data (yang sudah dijelaskan pada sub-bagian sebelumnya), reduksi data, penyajian data, dan penarikan simpulan atau verifikasi.

Berdasarkan pada hasil kajian dan analisis yang telah dilakukan atas 185 cerita anak yang terbit atau terpublikasikan pada Majalah Anak Bobo dan Harian Kompas, maka penalaran moral tokoh anak-anak dalam cerita anak dapat diidentifikasi melalui dua hal penting sebagai berikut.

\section{Tingkatan Penalaran Moral dalam Cerita Anak}

Penalaran moral dalam semua cerita-cerita anak pada Majalah Bobo dan Harian Kompas, setelah dilakukan analisis secara mendalam dan komprehensif, maka ditemukan kenyataan tingkat penalaran moral cerita-cerita anak yang merepresentasikan dua tingkatan, yaitu tingkatan prakonvensional dan tingkatan konvensional.

Pada tingkatan prakonvensional, ceritacerita anak pada Majalah Bobo dan Harian Kompas mencakup tahapan berorientasi hukuman dan relativis instrumen. Tahapan berorientasi hukuman ini direpresentasikan oleh cerita anak yang tokoh utama anaknya melakukan pelanggaran nilai moral, sehingga mendapatkan hukuman yang bersifat sebab akibat. Sedangkan, tahap relativis instrumen ini direpresentasikan oleh cerita-cerita anak yang tokoh utamanya melakukan perbuatan baik atau melakukan implementasi nilai moral dengan tujuan untuk mendapatkan hadiah yang menyenangkan.

Cerita-cerita anak pada tingkat prakonvensional ini menunjukkan tokoh-tokoh anak-anak 
yang "baik" dan "buruk" secara nyata. Tokoh yang baik adalah tokoh anak-anak yang memiliki kepribadian kepatuhan yang dominan atas nilai moral, sedangkan tokoh yang tidak baik adalah tokoh anak yang memiliki kepribadian tidak patuh atau melanggar nilai moral. Pada penalaran tingkat prakonvensional ini tokoh-tokoh ini terlibat dalam aktivitas atau perilaku moral yang bersumber pada "hukuman" dan "hadiah", yaitu tokoh anak-anak yang berbuat baik didasarkan pada takut karena adanya hukuman dan tokoh anak-anak yang berbuat baik karena bertujuan untuk mendapatkan hadiah. Kebaikan dilakukan karena orientasi pada ingin mendapatkan kesenangan atau terhindar dari hukuman.

Cerita-cerita anak menghadirkan tokoh utama anak yang mengalami problematika nilai moral, yaitu persoalan-persoalan moral yang harus diselesaikan. Dalam menyelesaikan persoalan nilai moral ini, tokoh utama anak melakukan dua kemungkinan orientasi utama: nilai moral dilanggar oleh tokoh utama anak sehingga mendapatkan hukuman yang berupa akibat atas perbuatannya dan nilai moral yang dijunjung tinggi dengan berorientasi untuk mendapatkan hadiah yang menyenangkan semata. Di sini, cerita anak-anak menyampaikan penalaran moral pada pembaca anak-anak untuk pentingnya berbuat baik karena adanya hukuman bagi yang salah dan adanya hadiah bagi yang menjunjung nilai moral.

Pada tahap prakonvensional ini, ceritacerita anak tampak menyampaikan peran nilai moral anak-anak yang bersifat transaksional. Perbuatan dalam mengaktualisasikan nilai moral hanya didasarkan pada transaksi-transaksi semata. Anak-anak harus berbuat baik dalam menjunjung nilai moral karena melalui perbuatan baik ini, anak-anak akan terhindar dari hukuman dan akan mendapatkan hadiah. Hukuman yang harus dihindari dan hadiah yang harus dicapai menjadi tujuan transaksi perbuatan moral anakanak.

Dengan mengetahui fakta hasil kajian ini, yaitu dominasi tingkatan prakonvensional dalam cerita-cerita anak di Majalah Bobo dan Kompas ini menunjukkan bahwa penalaran moral cerita-cerita anak yang rendah dan transaksional. Cerita-cerita anak harus mengajarkan anak-anak untuk selalu berbuat baik dan menjunjung nilai moral karena melalui kebaikan nilai moral anak-anak akan mendapatkan hadiah yang menyenangkan dan terhindar dari persoalan yang menyusahkan. Penalaran ini akan dipahami anak-anak sebagai pondasi pengetahuan dalam bersikap baik.

Kedua, pada tingkat konvensional, ceritacerita anak pada Majalah Bobo dan Harian Kompas hanya mencakup tahapan berorientasi anak baik. Tahapan berorientasi anak baik ini direpresentasikan oleh cerita-cerita anak yang tokoh utama anaknya melakukan kegiatan baik dalam menjunjung nilai moral karena tujuan yang lebih bersifat kemanusiaan,yaitu karena menjadi anak yang baik. Anak yang baik sebagai label kebanggaan atas dirinya yang dipersepsi anak yang baik tindakan moralnya.

Cerita-cerita anak pada tingkat konvensional yang berorientasikan pada anak baik menyajikan tokoh anak-anak yang berbuat moral baik karena orientasi ingin dikatakan atau diakui eksistensinya sebagai anak yang baik. Pada penalaran moral berorientasi anak baik ini tokoh-tokoh anak terlibat dalam aktivitas atau perilaku moral yang bertujuan adanya legitimasi eksistensial, baik yang berupa pengakuan ataupun sanjungan sebagai anak baik. Tokoh anak sudah berpersepsi bahwa 
perbuatan moral baik itu merepresentasikan kebaikan bagi yang melakukannya. Untuk itu, anak baik sebagai orientasi utama tingkatan ini menunjukkan sisi kemanusiaan anakanak.

Untuk itu, cerita-cerita anak pada tingkatan ini selalu menghadirkan tokoh utama anak yang pada awalnya mengalami problematika nilai moral, yaitu persoalanpersoalan moral yang ada dalam cerita anak, yang kemudian diselesaikan dengan dengan perbuatan baik yang berorientasikan pada pelabelan anak yang baik. Di sini tokoh utama anak menyelesaikan persoalan nilai moral dengan bertujuan yang eksistensial abstrak, bukan lagi berorientasi pada penghindaran beban hukuman dan hadiah yang menyenangkan. Cerita anak mulai menyampaikan sisi kemanusiaan anak yang baik, yaitu perbuatan baik anak akan selalu merefleksikan anak yang baik.

Pada tahap konvensional inilah, ceritacerita anak ini masih secara jelas menyampaikan peran nilai moral anak-anak yang masih bersifat transaksional. Transaksional yang sudah bersifat psikologis dan eksistensif. Perbuatan baik anak dalam mengaktualisasikan nilai moral telah didasarkan pada transaksi eksistensial. Anak-anak, jika ingin dikatakan sebagai anak yang baik, maka harus berbuat baik dalam menjunjung nilai moral karena melalui implementasi perbuatan baik ini, anak-anak akan akan mendapatka pengakuan eksistensial melalui pelabelan sebagai anak-anak yang baik pula.

Berdasarkan pada fakta hasil kajian ini, maka tingkatan konvensional dalam ceritacerita anak di Majalah Bobo dan Kompas ini yang tidak dominan ini merepresentasikan bahwa cerita-cerita anak masih berorientasikan penalaran moral dasar. Namun, adanya cerita anak yang penalaran moralnya konvensional berorientasi anak yang baik, maka ceritacerita anak juga menanamkan kesadaran eksistensial anak dalam bentuk kesadaran untuk berbuat moral baik tidak semata-mata karena ingin terhindar dari hukuman dan mendapatkan hadiah kesenangan, tetapi karena ingin adanya pengakuan eksistensial sebagai anak yang baik.

Dari analisis tingkatan penalaran moral cerita-cerita anak pada Majalah Bobo dan Harian Kompas dapat disimpulkan bahwa ceritacerita anak menyampaikan penalaran moral transaksional pada anak-anak, yaitu bahwa setiap perbuatan moral baik yang dilakukan anak selalu bertransaksi dengan orientasi terhindar dari hukuman, mendapatkan hadiah yang menyenangkan, serta dengan pelabelan sebagai anak yang baik. Namun, dengan dominasi cerita anak yang ada pada tahap prakonvensional ini menunjukkan bahwa cerita-cerita anak masih rendah penalaran moralnya karena anak-anak dikondisikan secara budaya untuk berbuat baik dengan orientasi untuk mendapatkan kesenangan dan ketakutan pada hukuman.

\section{Tahap Penalaran Moral Anak}

Dari aspek tahapan moralnya, yang menurut Kohlberg (1981) ada enam tahap penalaran moral, setelah dilakukan analisis mendalam terhadap 183 cerita anak yang dimuat dalam Majalah Bobo dan Harian Kompas, diidentifikasi dan ditemukan bahwa penalaran moral dalam cerita-cerita anak hanya pada tiga tahap, yaitu cerita anak dengan penalaran moral tahap satu: orientasi kepatuhan karena hukuman, penalaran moral tahap dua: berorientasi pada realativis instrumen, dan tahap tiga: berorientasi pada anak baik. Pembahasan setiap tahap penalaran moral dalam cerita anak sebagai berikut. 


\section{Cerita Anak dengan Penalaran Moral Kepatuhan Hukuman}

Menurut Santrock (2007: 119) penalaran moral berorientasi hukuman dan kepatuhanmerupakan tahap moralitas heterogen, yaitu tahap pertama pada tingkat penalaran awalanak-anak yang menunjukkan penalaran moral terkait dengan hukumankarena anak berpikir bahwa kepatuhan terjadi karena takut pada hukuman. Anak-anak harus melakukan tindakan dan sikap yang patuh agar tidak mendapatkan hukuman.

Cerita-cerita anak dengan penalaran moral kepatuhan pada hukuman menyajikan cerita anak dengan tokoh utama anak yang mengalami dilema moral, yaitu diketahuinya nilai moral yang harus dikerjakan dengan baik, tetapi di sisi lain ada dorongan egositas diri atau lingkungan yang kuat. Dorongan egositas ini berupa ajakan psikologis pada tokoh anak untuk melakukan penolakan atas kepatuhan anak pada nilai moral yang diketahuinya.

Hasilnya, pada cerita-cerita anak, yang berpenalaran moral kepatuhan hukuman ini, akan memenangkan dorongan egositas personal tokoh yang membawa ketidakpatuhan pada nilai moral yang diyakini. Egositas inilah yang kemudian membuat tokoh utama mengabaikan dan tidak melakukan tindakan moral. Anak melanggar dan tidak patuh. Anak melakukan suatu kesalahan moral. Karena sikap yang demikian, maka tokoh utama ini akan mendapatkan akibat atas kesalahan yang telah dilakukan tokoh utama anak-anak.

Oleh karena lebih memenangkan egositas personal anak, yang berdampak pada pengabaian nilai moral yang dipahami anak, maka tokoh anak dalam cerita anak akan mendapatkan hukuman. Hukuman dalam cerita anak lebih bersifat ketertekanan psikologis. Melalui dampak ketertekanan psikologis inilah, tokoh utama anak kemudian mendapatkan kesadaran. Kesadaran atas kesalahannya yang kemudian membawa dampak pada terbentuknya kepatuhan pada nilai moral oleh tokoh utama.

Misalnya, dalam cerita anak "Satu Gol untuk Bunda" di mana tokoh utama anak Attar mengalami dilema moral antara "keinginan untuk dibanggakan Ibunya karena berhasil mencetak gol pada pertandingan sepak bola yang telah diikuti" atau "berani mengatakan hal yang sebenarnya kalau dirinya" tidak mencetak gol.Dalam dilema moral demikian, Attar memilih untuk berbohong pada ibunya dan mengingkari nilai moral kejujuran. Attar kemudin berbohong pada ibunya. Dan usai berbohong, Attar mengalami kegelisahan sebagai hukuman atas perbuatan salahnya. Kegelisan ini puncaknya adalah mimpi buruk pada Attar. Setelah mendapatkan hukuman mimpi buruk ini, Attar kemudian mengakui kesalahannya.

Cerita-cerita anak dengan penalaran moral ini akan memberikan pemahaman pada anakanak yang membaca dengan dua kemungkinan moral: (1) anak-anak jangan melalukan tindakan yang salah, tindakan yang tidak sesuai nilai moral, karena nanti akan mendapatkan akibat sebagai hukumannya; dan (2) anak akan terhindar dari hukuman jika berbuat baik yang sesuai dengan nilai moral. Dengan dua nalar moral yang demikian, maka cerita-cerita anak dengan penalaran moral kepatuhan pada hukuman akan memberikan pemahaman pada anak bahwa dengan berbuat patuh pada nilai moral, maka anak-anak tidak akan mendapatkan hukuman. Hukuman menjadi dasar adanya kepatuhan nilai moral bagi anak-anak. 
Poetika: Jurnal Ilmu Sastra

Vol. VI No. 2 Desember 2018
DOI 10.22146/poetika.39017

ISSN 2338-5383 (print) ; 2503-4642 (online)

\section{Cerita Anak dengan Penalaran Moral Rela- tivis Instrumen}

Penalaran moral berorientasi relativis instrumenmerupakan tahap anak bernalar dalam memikirkan kepentingan dirinya sendiri, yaitu dalam mengenai hal yang benar, yang juga akan berlaku untuk orang lain. Anak mulai menalar tentang pertukaran setara, jika berbuat baik pada orang lain, maka orang lain akan berbuat baik juga pada dirinya, yaitu diberikannya sesuatu yang menyenangkan untuk anak (Santrock, 2011: 119).

Cerita-cerita anak dengan penalaran moral relativis instrumen ini selalu menceritakan tokoh utama anak yang mengalami persoalan moral antara hal ideal yang harus dilakukan dengan hal lain yang tidak pantas untuk dilakukan. Dalam problematika moral ini, tokoh utama akan memilih tindakan moral yang baik karena pengetahuannya bahwa setiap kebaikan pasti akan mendatangkankebaikan yang menguntungkan bagi dirinya, terutama keuntungan yang bersifat menyenangkan. Nilai keuntungan atau balasan kebaikan atas tindakan yang sesuai nilai moral ini yang kemudian menjadi tujuan utama anak-anak untuk berbuat baik pada teman-temannya.

Cerita-cerita anak yang berpenalaran berorientasi relativis instrumen ini akan memosisikan tokoh utama anak yang berhasil memenangkan dorongan untuk selalu berbuat baik sesuai dengan nilai moral. Dorongan egositas personal anak bisa dikalahkan. Keberhasilan dalam memenangkan dorongan nilai moral ini didasari oleh kesadaran anak-anak yang mulai memahami bahwa setiap kebaikan itu ada buah dan hasilnya, yang berupa balasan orang lain atas kebaikan yang kita lakukan. Wujud imbalan kebaikan itu adalah hadiah atau segala hal yang menyenangkan.
Dari sinilah, tokoh utama anak dalam ceritacerita anak berpenalaran moral relativis instrumen ini memosisikan perbuatan baik yang sesuai nilai moral ini sebagai media, sarana, dan alat untuk mendapatkan sesuatu yang menyenangkan itu. Perbuatan baik yang dilakukan tokoh utama lebih bersifat transaksional yang bertujuan, yaitu mendapatan imbalan kebaikan pula. Dari sinilah, kesadaran sosial yang sederhana mulai terbangun pada anak-anak, yaitu kesadaran bahwa kebaikan pada orang lain akan dibalas dengan kebaikan orang lain pada anak. Kebaikan yang tentu akan memberikan dampak kesenangan pada anak-anak.

Misalnya, dalam cerita anak "Cabai Emas" toko utama anak Connie adalah anak yang rajin memanfaatkan pekarangan rumahnya. Saat teman-temannya malas menanam, Connie rajin berkebun dan menanam cabai dengan penuh kasih sayang. Connie selalu merawat dan memelihara tanaman cabainya dengan baik. Sampai kemudian cabainya panen, dan saatpanen harganya sangat mahal sehingga Erwin menyebutnya cabai emas. Karena dengan hasil panen cabai,kemudian Connie bisa membeli perlengkapan sekolahnya, dan membeli emas untuk tabungan masa depannya.

Cerita-cerita anak dengan penalaran moral relativis instrumen ini memberikan pemahaman pada pembaca anak-anak bahwa dalam kehidupan anak-anak harus selalu berbuat baik, melalui kebaikan yang dilakukan maka anakanak akan mendapatkan hasil balasan yang menyenangkan. Di sisi lainnya, akan terbangun kesadaran bahwa cara terbaik untuk mendapatkan sesuatu yang menyenangkan adalah dengan berbuat baik. Perbuatan baik kemudian dijadikan sebagai sarana untuk mendapatkan hal yang menyenangkan dalam melakukan perbuatan yang sesuai dengan nilai moral baik. 
Cerita Anak dengan Penalaran Moral Orientasi Anak Baik

Penalaran moral yang berorientasi anak baik adalah penalaran moral yang memosisikan anak sebagai individu sudah menghargai kepercayaan, perhatian, dan kesetiaan terhadap orang lain sebagai dasar penalaran moralnya. Anak-anak sudah memiliki kesadaran untuk berbuat baik karena ingin mendapatkan pengakuan sebagai anak yang baik dari anak-anak lainnya. Dari sinilah pada tahap penalaran moral ini menunjukkan peralihan anak ke remaja yang sering kali mengadopsi standar moral orang tua agar dianggap orang tua sebagai anak yang baik (Santrock, 2007: 119 \& Crain, 2007: 233);

Cerita-cerita anak dengan penalaran moral berorientasi anak baik menyajikan tokoh utama anak yang dengan kesadarannya, saat mengalami problematika moral, mampu menyelesaikannya dengan memilih moral yang baik. Pemilihan sikap moral baiknya didasarkan pada kesadaran bahwa berbuat sesuai dengan nilai moral yang baik adalah keharusan yang dilakukan sebagai wujud atas kesadaran dirinya sebagai individu sosial. Dengan kesadaran ini, anak-anak berbuat baik, tidak semata-mata karena ingin mendapatkan imbalan hadiah atau menghindari hukuman, tetapi berbuat baik dilakukan karena ingin disebut sebagai anak baik sehingga bisa diterima eksistensinya sebagai anak yang baik.

Cerita-cerita anak dengan penalaran moral orientasi anak baik ini menempatkan posisi tokoh utama sebagai anak yang dalam menghadapi problematika moral langsung mengerti cara menyelesaikannya dengan baik melalui pilihan sikapmoral yang baik. Pilihan sikap moral ini didasarkan pada kesadaran anak yang memahami bahwa hakikat setiap tindakan itu harus baik karena melalui tindakan yang baik nantinya dirinya akan mendapatkan posisi sosial anak yang bagus, yaitu sebagai anak yang baik. Melalui status dan label anak yang baik, maka anak-anak lain akan menerima, menghormati, dan berbuat baik pula pada anak. Dari kebaikan ini, anak akan mendapatkan kelompok sosial yang baik sebagai tempat untuk membangun interaksi dan komunikasi.

Dari sinilah, tokoh utama anak dalam ceritacerita anak berpenalaran moral orientasi anak baik menghadirkan tokoh utama anak yang sudah memiliki kesadaran sosial tinggi, yang bisa jadi menjadi peralihan dari anak-anak ke remaja. Tokoh utama sudah memiliki pilihan moral yang baik, dan pilihannya didasarkan pada motivasi moral sosial yang baik. Di sinilah, tahap tertinggi penalaran moral anak-anak yang ada dalam cerita anak. Cerita anak-anak pun menyajikan tokoh moral yang orientasinya pada kebaikan sosial.

Misalnya, dalam cerita anak "Teman Kecil? Siapa Takut!" dengan tokoh utama Pako yang awalnya protes karena diminta berangkat sekolah dengan Nino yang masih anak TK. Tapi, setelah berpikir dengan cermat, Pako kemudian mencoba karena ketaatannya pada orang tuanya. Pako pun mau berangkat bersama dengan Nino. Dengan keputusan menjadi anak yang baik, Pako pun bersahabat Nino yang ternyata menyenangkan. Pako juga menjadi disayang orang tuanya dan teman-teman lainnya. Melalui keputusan moral yang baik, Pako pun menjadi anak baik bagi Ayah dan Ibu serta Nino dan teman-temannya.

Cerita-cerita anak dengan penalaran moral anak baik ini memberikan pemahaman pada pembaca bahwa anak-anak, dalam menghadapi problematika moral, harus memilih pilihan tindakan yang baik. Melalui tindakan yang baik, 
anak-anak akan mendapatkan akses sosial yang baik. Anak akan disebut sebagai anak baik yang keberadaannya akan diterima dan mendapat posisi yang baik dalam kelompokkelompok sosialtertentu, misalnya, keluarga, sekolah, pertemanan, sampai masyarakat.

Dari ketiga tahapan penalaran moral di atas, cerita-cerita anak dalam Majalah Bobo dan Harian Kompas didominasi oleh penalaran moral relativis instrumen dan orientasi anak baik. Hal ini menunjukkan bahwa cerita-cerita anak merepresentasikan kesadaran kolektif untuk melakukan pendidikan kebaikan dengan semestinya, yaitu anak dididik dengan orientasi memberikan penghargaan atas kebaikan dan membangun kesadaran berbuat baik karena eksistensi anak baik. Dari sini cerita-cerita anak menginginkan anak-anak yang memiliki daya berprestasi yang baik, serta bebuat baik sebagai bentuk tanggung jawab atas kenyataan kehidupan sosial anak. Dengan berorientasi pada dua hal inilah, maka cerita anak yang hanya berorientasi pada penalaran moral hukuman sudah saatnya mulai ditinggalkan. Mengajak anak-anak dalam kebaikan dengan hukuman menjadi kurang relevan dalam tumbuh kembang anak.

\section{Kesimpulan}

Pertama, penalaran moral anak-anak dalam cerita-cerita anak disampaikan dalam dua tingkatan moral, yaitu tingkatan penalaran moral prakonvensional dan tingkatan penalaran moralkonvensional. Pada tingkatan prakonsvensional, cerita-cerita anak menyampaikan penalaran moral yang berorientasikan pada hukuman dan hadiah, yaitu cerita anak menceritakan keputusan moral baik tokoh utama anak karena berorientasikan pada adanya hukuman dan untuk mendapatkan hadiah. Sedangkan, pada tingkatan konvensional, cerita anak menyampaikan penalaran moral yang berorientasikan anak baik, anak-anak harus berbuat baik agar disebut anak baik yang akan diterima dikelompoknya.

Kedua,tahapan penalaran moral dalam cerita anak hanya tiga tahap dari enam tahap yang ada. Ketiga tahap ini adalah tahap orientasi kepatuhan hukuman, relativis instrumen, dan orientasi anak baik. Dari ketiga tahap penalaran moral tersebut, penalaran moral relativis instrumen dan orientasi anak baik mendominasi penalaran moral dalam cerita-cerita anak. Hal ini merefleksikan kenyataan psikologis dan sosiologis kehidupan anak-anak bahwa motivasi anak-anak dalam berbuat baik (moral) karena ingin mendapat kesenangan dan dsebut anak baik yang bisa diterima dalam kelompok sosial yang baik.

\section{Daftar Pustaka}

Bertens, K. 2007. Etika. Jakarta: Penerbit Gramedia.

Duska, Ronald \& Mariellen Whelan. 1982. Moral Development: A Guide ti Piaget and Kohlberg. New York: Paulist Press.

Huck, Charlotte S, dkk. 1987. Children's Literature in The Elementary School. New York: Holt Rinehart and Winston.

Hunt, Peter. 1995. Criticism, Theory, and Children's Literature. Cambridge: Blackwell Press.

--- (Ed.). 2004. Internasional Companion Encyclopedia of Children's Literature. London and new York: Routledge.

Hurlock, Elizabeth B. 1991. Perkembangan Anak 2. Terj. Meitasari Tjandrasa. Jakarta: Penerbit Erlangga.

Kohlberg, Lawrance. 1980. "Stages of Moral Development as a Basis for Moral Education" dalam Brenda Munsey (Ed.). Moral Development, Moral Education, and Kohlberg: Basic Issues in Philosophy, Psychology, Religion, and Education. Birmingham Albama: Scott Religion Education Press. 
Poetika: Jurnal Ilmu Sastra

Vol. VI No. 2 Desember 2018

1981. The Philosophy of Moral Development Stages and Idea. San Fransisco: Harper and Row.

-. 1995. Tahap-tahap Perkembangan Moral. Terj. John de Santo dan Agus Cremers. Yogyakarta: Penerbit Kanisius.

Lukens, Rebecca J. 2003. A Critival handbooks of Children's Literature. New York: Longman.

Magnis-Suseno, Frans. 2000. Etika: Sebuah Analisis Falsafi. Jakarta: Penerbit Gramedia.

Miles, Matthew B. dan A. Michael Huberman. 2009. Analisis Data Kualitatif. Terj. Tjetep rohendi Rohidi. Jakarta: UI Press.

Nurgiyantoro, Burhan. 2010. "Sastra Anak: Persoalan Genre" dalam Jurnal Humaniora Volume 16, No. 2, Juni 2004. Yogyakarta: Universitas Gadjah Mada Yogyakarta.

Purbani, Widyastuti. 2003. "Ideologi Anak Ideal dalam Lima Fiksi Anak Unggulan Indonesia Akhir Masa Orde Baru (Studi Kasus Tentang Fiksi-fiksi
Pemenang Sayembara Penulisan Naskah Fiksi Anak Depdiknas dan Penerima Penghargaan Buku Bacaan Anak Nasional Tahun 1996-2001)" dalam DISERTASI. Jakarta: Universitas Indonesia.

Ratna, Nyoman Kutha. 2011. Teori, Metode, dan Teknik Penelitian Sastra: dari Strukturalisme hingga Poststrukturalisme Perspektif Wacana Naratif. Yogyakarta: Pustaka Pelajar.

Santrock, J.W. 2007. Psikologi Pendidikan (edisi kedua). Terj. Tri Wibowo B.S. Jakarta: Kencana.

---------. 2011. Perkembangan Anak 1. Terj. Mila Rachmawati dan Anna Kuswanti. Jakarta: Erlangga.

-------. 2012. Perkembangan Anak 2. Terj. Mila Rachmawati dan Anna Kuswanti. Jakarta: Erlangga.

Saxby, Maurice \& Gordon (Ed). 1991. Give Them Wings: The Experience of Children's Literature. Melbourne: The Macmillian Company.

Wellek, Rene and Austin Warren. 1995. Theory of Literature. New York: Harcourt, Brace and World Inc. 